\title{
Protoporphyrinogen Oxidase Inhibitor Herbicide Effects on Pythium Root Rot of Sugarcane, Pythium Species, and the Soil Microbial Community
}

\author{
J. H. Daugrois, J. W. Hoy, and J. L. Griffin
}

First author: Cirad-ca, Station de Roujol 97170 Petit Bourg, Guadeloupe; second author: Department of Plant Pathology and Crop Physiology, Louisiana State University Agricultural Center, Baton Rouge 70803; and third author: Department of Agronomy and Environmental Management, Louisiana State University Agricultural Center. Accepted for publication 15 September 2004.

\begin{abstract}
Daugrois, J. H., Hoy, J. W., and Griffin, J. L. 2005. Protoporphyrinogen oxidase inhibitor herbicide effects on Pythium root rot of sugarcane, Pythium species, and the soil microbial community. Phytopathology 95:220-226.

The effects of three protoporphyrinogen oxidase inhibitor herbicides, azafenidin, flumioxazin, and sulfentrazone, on Pythium root rot of sugarcane and the soil microbial community were evaluated in greenhouse experiments. Herbicides were applied as foliar and soil treatments. There

ever, some herbicide treatments affected the relative frequency of isolation of Pythium spp. from roots and reduced colonization by the pathogenic species Pythium arrhenomanes. A comparison of sole carbon source utilization profiles indicated that soil-applied herbicides altered the functional diversity of the soil microbial community, with some variation depending on herbicide used. All three herbicides inhibited the in vitro mycelial growth of $P$. arrhenomanes, $P$. aphanidermatum, and P. ultimum. Active ingredients were less inhibitory than formulated product for azafenidin and flumioxazin but not for sulfentrazone.
\end{abstract} were no consistent effects on plant growth or disease parameters. How-
Sugarcane, interspecific hybrids of Saccharum, is a clonally propagated crop from which multiple, successive annual harvests of stalks typically are obtained. Yield can be adversely affected by diverse biological factors, including a soilborne disease complex and weed competition. Pythium root rot, caused primarily by Pythium arrhenomanes, is an important component of the root disease complex in more temperate climatic regions $(12,17,25)$. Aboveground obvious disease symptoms are not observed in modern interspecific hybrid cultivars, but reduced tillering and stalk weight can result from rotting of young roots by Pythium spp. Sugarcane often is grown as a monoculture, and evidence suggests that long-term cultivation of sugarcane can result in changes in the soil microbial community that are detrimental to plant growth $(8,20,21)$.

Weeds are controlled through tillage and herbicide applications. The effects of six herbicides routinely applied to sugarcane in Louisiana on plant growth, root rot, and Pythium mycelial growth were evaluated in a previous study (4). Two herbicides, pendimethalin and atrazine, inhibited the mycelial growth of $P$. arrhenomanes, but neither reduced root rot severity in greenhouse experiments. Three herbicides, glyphosate, pendimethalin, and terbacil, were injurious to sugarcane and increased root rot severity. Metribuzin had no effect on root rot or mycelial growth.

Since the previous herbicide study, three protoporphyrinogen oxidase (PPOase) inhibitor herbicides, azafenidin (30), flumioxazin, and sulfentrazone (30), have been evaluated for postemergence weed control in Louisiana. Herbicides that inhibit PPOase result in the generation of singlet oxygen radicals that destroy lipids in cell membranes. A variety of PPOase inhibitor herbicides have been demonstrated to reduce the severity of Sclerotinia stem

Corresponding author: W. Hoy; E-mail address: jhoy @agctr.lsu.edu

DOI: 10.1094/PHYTO-95-0220

(C) 2005 The American Phytopathological Society rot of soybean $(3,22,23)$, reduce soybean cyst nematode reproduction (18), and reduce severity of Rhizoctonia aerial blight of soybean (1). Reduced disease severity is associated with enhanced defense mechanisms, including elicitation and accumulation of phytoalexin and mimicry of the hypersensitive response $(14,22,23)$.

There has been long-standing interest in the effects of herbicides on soil microflora $(10,26)$. Sole carbon source utilization profiles (7) have been used to evaluate soil microbial community functional diversity in agricultural cropping systems $(5,6,16,19)$. PPOase inhibitor herbicides are subject to soil adsorption, but their possible effects on soil microflora are unknown.

Field observations suggested the possibility of enhanced sugarcane growth resulting from azafenidin treatments without weed competition or visible disease symptom differences between treated and nontreated portions of fields. These observations prompted a study to evaluate the effects of PPOase inhibitor herbicides on Pythium spp. and root rot in sugarcane. Due to the complex nature of soilborne disease in sugarcane, possible effects of the PPOase inhibitor herbicides on the soil microbial community also were examined.

\section{MATERIALS AND METHODS}

Two experiments were conducted in the greenhouse during fall 2000 and winter 2001. Maximum and minimum average temperatures were 28 and $17^{\circ} \mathrm{C}$ for the fall experiment and 30 and $17^{\circ} \mathrm{C}$ for the winter experiment. The soil used in both experiments was a Commerce silt loam collected from a sugarcane field at the St. Gabriel Research Station of the Louisiana State University Agricultural Center in Iberville Parish. Soil was sieved through a 1-cm-mesh screen and mixed. A portion of soil was steam sterilized by exposure to steam for $24 \mathrm{~h}$ in metal trays ( 50 by 70 by $8 \mathrm{~cm}$ ). Nonsterile or steam-treated soil then was mixed with steam-treated sand to a final field soil/sand ratio of $1: 1$ ( $\mathrm{vol} / \mathrm{vol})$. Untreated field soil mixed with steam-treated sand will be 
referred to as field soil (FS), and the steamed field soil-sand mixture will be referred to as steamed field soil (SFS). A portion of SFS was infested with $P$. arrhenomanes inoculum and will be referred to as $P$. arrhenomanes-infested SFS (SFS $+\mathrm{P})$. The $P$. arrhenomanes inoculum was prepared and added to soil as described previously (12). Inoculum consisted of mycelium and reproductive structures produced in a mixture of vermiculite, oat, and V8 vegetable juice that was added to the potting medium after rinsing at a ratio of 1:50.

Herbicide effects were evaluated on sugarcane transplants grown in clay pots. Four-week-old plants of cv. LCP 85-384 with three to four leaves, grown from single-bud cuttings, were transplanted in 15-cm-diameter clay pots (one plant per pot). Two herbicide applications were made: foliar application and soil application. For the herbicide leaf application treatment, herbicides were applied to plant foliage just before transplantation. Roots and soil were protected from contact with herbicide spray by covering soil with plastic film. For the herbicide soil application treatment, herbicides were applied to the soil surface just after plants were transplanted in clay pots. Foliage was protected from herbicide spray by wrapping the leaves in plastic film. Commercial formulations of three herbicides, azafenidin (Milestone DF 80; DuPont De Nemours \& Co. Inc., Newark, DE), flumioxazin (Valor DF 50; Valent USA Corporation, Walnut Creek, CA), and sulfentrazone (Spartan DF 75; FMC Corporation, Philadelphia) were applied at the recommended rates $(0.57,0.28$, and $0.285 \mathrm{~kg}$ a.i./ha for Milestone, Valor, and Spartan, respectively) and 1/10 of the recommended rates in both experiments. Azafenidin and sulfentrazone are in the aryl triazinone chemical family, and flumioxazin is an N-phenylphthalimide. After extensive testing, azafenidin was not labeled for commercial use. Control treatments with no herbicide application were included for comparison with herbicide treatments for all soil types. The herbicides were applied to plants in a spray chamber. The sprayer was calibrated to deliver 140 liter ha $\mathrm{ha}^{-1}$ at a pressure of 1.65 bar.

Five plants per treatment were randomly placed on two greenhouse benches. On each bench, the three soil types, FS, SFS, and $\mathrm{SFS}+\mathrm{P}$, were separated by clear plastic film barriers to prevent cross contamination. Plants were watered daily to maintain the soil moisture level near field capacity. Plants were fertilized every 2 weeks with a water-soluble fertilizer mixture (N-P-K, 20-2020 ). Plant injury caused by herbicides was recorded at 15,30 , and 45 days after herbicide treatments, using a 0-to-5 rating scale, in which $0=$ no damage, $1=<5 \%$ of the leaf surface exhibiting chlorosis and necrosis, $2=>5$ to $20 \%$ injury, $3=>20$ to $50 \%$ injury, $4=>50$ to $90 \%$ injury, and $5=$ plant death. Plant injury data were analyzed after calculation of the area under the herbicide damage progress curve (AUHDPC).

Evaluation of herbicide effects on root rot, plant growth, and Pythium spp. colonization. The effects of herbicides were evaluated 8 to 10 weeks after treatment. Plant data recorded included total shoot number per plant, root system fresh weight, and total shoot dry weight. In addition, a visual rating of root system reduction and root rot in comparison with the appropriate control was made for each plant on a scale of 1 to 4 , in which $1=$ normal appearance, no discoloration or reduction of lateral root system; $1.5=$ very mild disease, less than $10 \%$ root discoloration or reduction in lateral root system; $2=$ mild disease, 10 to $25 \%$ damage, $2.5=$ moderate disease, 26 to $50 \%$ damage; $3=$ severe disease, 51 to $75 \%$ damage; $3.5=$ very severe disease, 76 to $90 \%$ damage; and 4 = complete disease.

The extent of root colonization by Pythium spp. also was determined. Six root samples, $5 \mathrm{~cm}$ in length, were collected from each of five plant replicates per treatment. Root segments were washed in deionized water on a rotary shaker, blotted dry, placed in a 9 -cm-diameter petri dish, and immersed in molten selective medium at $50^{\circ} \mathrm{C}$. The medium contained $10 \mathrm{~g}$ each of corn meal agar and agar autoclaved in 1 liter of distilled water. It was amended after cooling to $50^{\circ} \mathrm{C}$ with $15 \mathrm{mg}$ of pentachloronitrobenzene dissolved in $95 \% \mathrm{EtOH}, 250 \mathrm{mg}$ of ampicillin and $10 \mathrm{mg}$ of rifampicin dissolved in $1 \mathrm{ml}$ of distilled water, and $0.4 \mathrm{ml}$ of pimaricin (10 mg a.i./liter). The agar was allowed to harden, and the number of $\mathrm{cm}$ of root colonized by Pythium spp. was determined after 24 and $48 \mathrm{~h}$ at room temperature. Forty isolates were collected from infected roots for identification from each FS treatment.

Pythium isolates from root samples were identified as described previously (4). Isolates were transferred to individual petri dishes containing V8 medium (200 $\mathrm{ml}$ of V8 vegetable juice, $2 \mathrm{~g}$ of $\mathrm{CaCO}_{3}$, and $17 \mathrm{~g}$ of Bacto agar). After 24 to $48 \mathrm{~h}$ of growth, six 3 -mm-diameter agar plugs containing actively growing mycelium were transferred into a $5.5-\mathrm{cm}$-diameter petri dish and flooded with 5 to $7 \mathrm{ml}$ of filter-sterilized soil extract. After 2 to 3 days at room temperature, identification of Pythium spp. was accomplished by microscopic examination of reproductive structures using the key of Van der Plaats-Niterink (29).

Characterization of soil microbial communities. To determine herbicide effects on the soil microbial community, soil samples from each full rate soil herbicide treatment were sampled as described by Fantroussi et al. (5) with some modifications. Briefly, soil samples were collected with a soil core at a depth of 3 to $5 \mathrm{~cm}$ from four different pots, pooled, and mixed. Three subsamples of $5 \mathrm{~g}$ of soil were taken from the pooled soil before extraction of microorganisms from soil. Isolation of microorganisms was performed by modifying the methods of Smalla (27) and Staddon et al. (28). Subsamples were suspended separately in $25 \mathrm{ml}$ of sterile saline solution $(0.85 \% \mathrm{NaCl})$, and agitated for $1 \mathrm{~h}$ on a rotary shaker at $200 \mathrm{rpm}$ at room temperature. The soil suspension then was centrifuged for $10 \mathrm{~min}$ at $500 \times g$ to remove soil and root particles. The supernatant was transferred to a sterile centrifuge tube. Microorganisms were washed twice with $20 \mathrm{ml}$ of sterile saline solution $(10,000 \times g$ for $10 \mathrm{~min})$ and then suspended in $40 \mathrm{ml}$ of sterile saline solution. GN2 and GP2 Biolog (Biolog Inc., Hayward, CA) plates for gram-negative and -positive bacteria were inoculated with $140 \mu \mathrm{l}$ of washed microorganisms per well and incubated at $28^{\circ} \mathrm{C}$ for 5 days. Absorbance readings were made each day with a microplate autoreader at $600 \mathrm{~nm}$ with blanking done on well A1. The experiment was conducted twice, 4 and 6 weeks after herbicide treatments.

For both experiments, results from the third day for a total of 128 substrates (maximum values for duplicated substrates in GN2 and GP2 plates were used) were compared for the two experiments combined. The number of variables was reduced to 69 by discarding single carbon sources with values below 0.5 and, as recommended by Glimm (9), variables with well means above 2.0 also were discarded. Standardization of optical density (OD) values was performed as proposed by Garland and Mills (7). Briefly, each OD value from one plate was divided by the average well color development (AWCD) of the plate. AWCD was used as a general indicator of microbial activity.

Evaluation of herbicide effects on in vitro mycelial growth of three Pythium spp. Cornmeal agar (Difco Laboratories, Detroit) was amended after sterilization with the commercial formulation and the pure active ingredient of azafenidin, flumioxazin, and sulfentrazone at 2, 1, 0.5, 0.1, 0.05, 0.01, 0.005, and 0 times the recommended application rates $(0.57,0.28$, and $0.28 \mathrm{~kg}$ a.i. ha ${ }^{-1}$, respectively). The concentrations of herbicide active ingredient for rate one were $3,1.5$, and $1.5 \mathrm{~g} \mathrm{liter}^{-1}$ for azafenidin, flumioxazin and sulfentrazone, respectively.

Agar plugs, $3 \mathrm{~mm}$ in diameter, were removed from the margins of actively growing colonies of $P$. arrhenomanes, $P$. aphanidermatum, and $P$. ultimum, placed in the center of herbicide-amended plates, and incubated at $25^{\circ} \mathrm{C}$. Radial growth of mycelium from the center was recorded at 24 and $48 \mathrm{~h}$. A mycelial growth rate per $24 \mathrm{~h}$ then was calculated. Each treatment was replicated four times. The experiment was conducted twice. 
Statistical analyses. SAS (version 8.2; SAS Institute Inc., Cary, NC) was used for data analysis. Herbicide effects on Pythium root rot and plant growth were analyzed as follows. All results from one type of soil and one herbicide rate were combined and analyzed together with herbicide and application as fixed effects and experiment as a random effect. SAS mixed procedure was used to analyze the herbicide application treatment effects, and least square means were used to compare treated plants to nontreated control plants. Percent of root length colonized by Pythium spp. was analyzed after angular transformation ( $x=$ arcsine [sqrt $(L / 30)]$ ) where $L=$ length of root colonized by Pythium spp. out of the $30 \mathrm{~cm}$ plated. Normality of the data was controlled under univariate procedure. Root rot severity and AUHDPC data were analyzed by GLM procedure with herbicide and application as combined sources of variation and experiments as repeated measures. Single carbon source utilization profiles were analyzed by principal component analysis using the covariance matrix.

\section{RESULTS}

Herbicide effects on plant growth and Pythium root rot. Recommended rate herbicide treatments were applied separately on leaves of cv. LCP 85-384 and on soil. Azafenidin applied to either the leaves (HLA) or the soil (HSA) was phytotoxic to plants (Fig. 1A). Plant death resulted from soil application in SFS, and extensive leaf necrosis and reduced plant growth was observed for the other soil types. Other herbicide treatments pro-

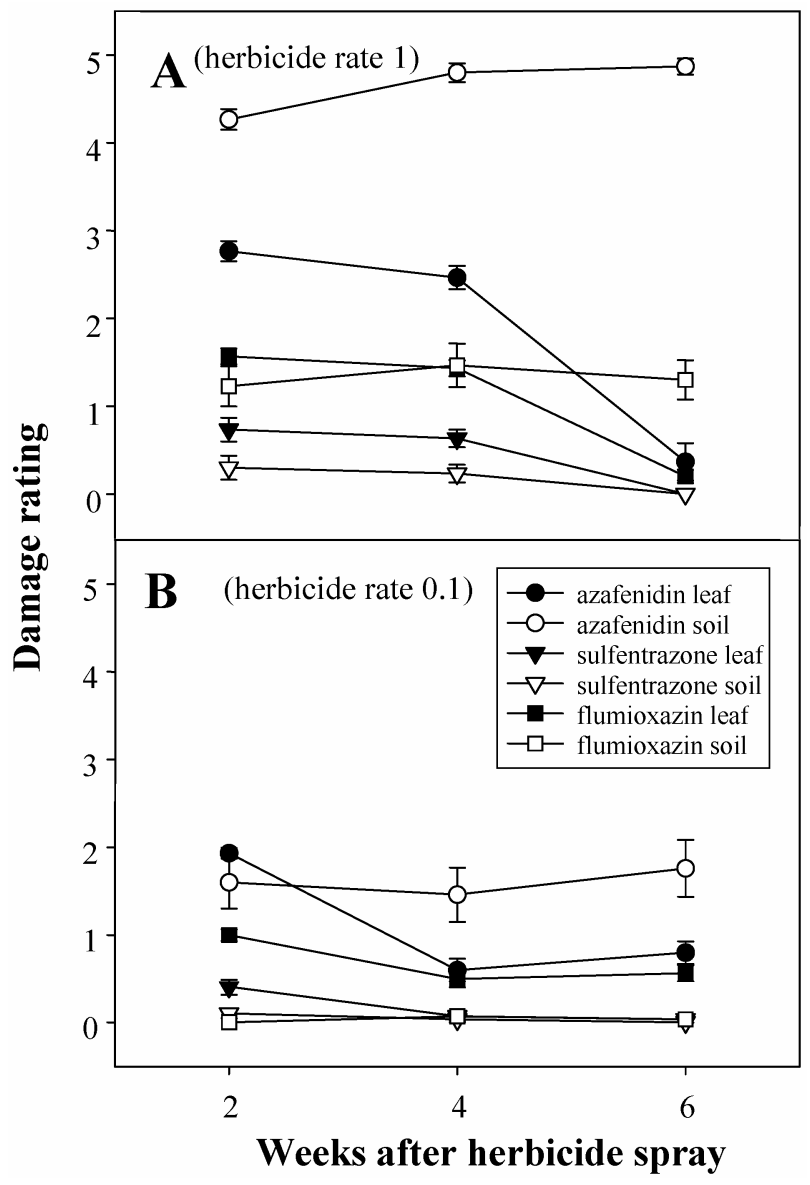

Fig. 1. Evaluation of phytotoxicity symptoms caused by herbicide treatments at two rates, $\mathbf{A}$, full recommended rate (1.0) and $\mathbf{B}, 1 / 10$ the full rate $(0.1)$. Results of two experiments were combined. Data points represent means of each herbicide treatment for each date of rating, and error bars are the standard error of the mean. Azafenidin was not applied to soil at the full rate in experiment two. duced only minor necrosis on SFS $+\mathrm{P}$ and FS plants, and damage decreased during the experiment (Fig. 1A). Due to plant deaths, results for azafenidin applied to soil at the full rate were discarded from the statistical analysis.

Overall, no effect of the full rate of herbicide application either on soil or leaf was observed on shoot weight for either FS or $\mathrm{SFS}+\mathrm{P}$ plants, and only one treatment, flumioxazin applied to soil, was significantly different from the control (Table 1). Compared with control plants, two full-rate herbicide treatments had a negative effect on root growth. Flumioxazin applied to soil reduced root weight by 29 and $36 \%$ on FS and SFS+P plants, respectively, and also caused a $44 \%$ reduction for SFS plants (Table 1). Azafenidin applied to leaves at the full rate also reduced root weight of FS and SFS plants by 30 and $24 \%$, respectively. All three herbicides had a negative effect on root weight of SFS plants when applied at full rate to soil (Table 1). For full-rate herbicide treatments, no significant effect on root colonization by total Pythium spp. was observed; however, colonization by $P$. arrhenomanes was reduced by sulfentrazone and flumioxazin applied to soil in FS (Table 1). There was no effect on root rot severity rating (data not shown).

When herbicides were applied at the 0.1 rate, the only negative herbicide effects on plant growth were due to azafenidin applied to soil in FS and SFS and flumioxazin applied to soil in SFS+P (Table 2). At rate 0.1 of the recommended herbicide rate, visible damage observed on plants was reduced (Fig. 1B). All other root and shoot weights for herbicide-treated plants and control plants were similar, except sulfentrazone applied to soil increased root weight $(P=0.056)$ in SFS $+\mathrm{P}$ (Table 2$)$. There were variable effects of herbicide treatments on Pythium spp. root colonization (Table 2). Colonization by Pythium spp. and P. arrhenomanes was decreased by foliar application of flumioxazin in FS $(P=0.095$ and 0.078 , respectively) and colonization by $P$. arrhenomanes was decreased by sulfentrazone applied to leaves in SFS $+\mathrm{P}(P=$ 0.003). However, colonization by Pythium spp. was increased by sulfentrazone soil application in FS. For flumioxazin and sulfentrazone applied to SFS+P and FS plants, root colonization by Pythium spp. was significantly higher for rate 0.1 applied to soil than for rate 0.1 applied to leaves. Only flumioxazin applied to leaves in SFS $+\mathrm{P}$ significantly reduced the root rot severity rating (Fig. 2).

Herbicide effects on Pythium spp. isolation from sugarcane roots. Pythium spp. were identified and quantified after isolation in each experiment. Results showed that azafenidin applied to leaves at the full rate $(P=0.036)$ and sulfentrazone and flumioxazin applied to soil at the full rate $(P=0.017)$ on FS plants significantly reduced the percentage of isolates that were $P$. arrhenomanes (Fig. 3A). The percentage of isolates consisting of other species increased from $29 \%$ (control plants) to $67 \%$ for soilapplied flumioxazin and $60 \%$ for soil-applied sulfentrazone and azafenidin applied to leaves at the full rate. Other Pythium spp. identified on FS were $P$. spinosum, $P$. graminicola, $P$. irregulare, and $P$. torulosum (Fig. 3). Some herbicides appeared to change profiles of species isolated from infected roots. Sulfentrazone and flumioxazin applied to soil at the full rate and sulfentrazone applied to soil at rate 0.1 significantly enhanced occurrence of $P$. tolurosum $(P=0.018,0.033$, and 0.023 , respectively, for the three herbicide applications), and the percentage of isolates identified as $P$. spinosum was significantly higher for sulfentrazone and azafenidin applied to soil at rate $0.1(P=0.013$ and 0.010) (Fig. 3B).

Herbicide effects on the soil microbial community. Soil microbial community functional diversity evaluated by sole carbon substrate utilization profile was affected by herbicide treatment in FS. No differences between treatments were observed for AWCD values calculated for each Biolog plate. Means for AWCD values ranged from 0.71 for azafenidin treatment to 0.87 for the untreated control. The first principal component (PC1), representing 
$27 \%$ of the standardized variance of carbon source utilization, corresponded mainly to differences between sampling dates. The difference between sampling dates also was observed for PC2. On the other hand, PC2 clearly separated the microbial community under flumioxazin treatment from communities affected by the two other herbicide treatments (Fig. 4A). PC3 and PC4 were not representative of variation between sampling dates. However, PC3 differentiated microbial communities for the azafenidin and control treatments from microbial communities for the sulfentrazone and flumioxazin treatments. PC4 differentiated microbial com- munities under all three herbicide treatments from the microbial community of control soil (Fig. 4B). Carbon substrates most responsible for explaining variability in substrate utilization were carbohydrates (Table 3).

Herbicide effects on mycelial growth of Pythium spp. in vitro. Commercial formulations of all herbicides reduced $P$. arrhenomanes, $P$. aphanidermatum, and $P$. ultimum mycelial growth even at the lowest herbicide concentration (Fig. 5). The lowest concentration used was $0.0187,0.015$, and $0.01 \mathrm{~g} \mathrm{liter}^{-1}$ for azafenidin, flumioxazin, and sulfentrazone, respectively. Those

TABLE 1. Effects of recommended-rate herbicide treatments on root colonization by Pythium spp. and root and shoot weight ${ }^{\mathrm{a}}$

\begin{tabular}{|c|c|c|c|c|c|c|}
\hline \multirow[b]{2}{*}{ Soil $^{\mathrm{b}}$} & \multirow[b]{2}{*}{ Herbicide } & \multirow[b]{2}{*}{ Application } & \multicolumn{2}{|c|}{ Length of root colonized (out of $30 \mathrm{~cm}$ ) } & \multirow[b]{2}{*}{ Root weight (g) } & \multirow[b]{2}{*}{ Shoot weight $(\mathrm{g})^{\mathrm{d}}$} \\
\hline & & & Pythium spp. & P. arrhenomanes ${ }^{\mathrm{c}}$ & & \\
\hline FS & Control & None & 6.3 & 3.9 & 10.4 & 4.1 \\
\hline FS & Azafenidin & Leaf & 8.5 & $2.6^{*}$ & $7.3 * *$ & 3.4 \\
\hline FS & Sulfentrazone & Leaf & 4.3 & $2.7 *$ & 10.3 & 4.2 \\
\hline FS & Flumioxazin & Leaf & 10.2 & 5.9 & $8.3^{*}$ & 3.9 \\
\hline FS & Sulfentrazone & Soil & 4.7 & $2.2 * *$ & 9.5 & 3.6 \\
\hline FS & Flumioxazin & Soil & 4.5 & $1.2 * * *$ & $7.4 * *$ & 3.7 \\
\hline FS & Azafenidin & Soile & $\ldots$ & $\ldots$ & 1.2 & 0.7 \\
\hline $\mathrm{SFS}+\mathrm{P}$ & Control & None & $\ldots$ & 20.6 & 10.4 & 4.5 \\
\hline $\mathrm{SFS}+\mathrm{P}$ & Azafenidin & Leaf & $\ldots$ & 19.8 & 9.1 & 3.9 \\
\hline $\mathrm{SFS}+\mathrm{P}$ & Sulfentrazone & Leaf & $\ldots$ & 16.9 & 10.3 & 4.0 \\
\hline $\mathrm{SFS}+\mathrm{P}$ & Flumioxazin & Leaf & $\ldots$ & 24.0 & 10.0 & 4.3 \\
\hline $\mathrm{SFS}+\mathrm{P}$ & Sulfentrazone & Soil & $\ldots$ & 19.1 & 9.6 & 3.8 \\
\hline $\mathrm{SFS}+\mathrm{P}$ & Flumioxazin & Soil & $\ldots$ & 19.7 & $6.6^{* *}$ & $3.1 * *$ \\
\hline $\mathrm{SFS}+\mathrm{P}$ & Azafenidin & Soile & $\ldots$ & $\ldots$ & 0.6 & 0.3 \\
\hline SFS & Control & None & $\ldots$ & $\ldots$ & 33.9 & 7.6 \\
\hline SFS & Azafenidin & Leaf & $\ldots$ & $\ldots$ & $25.6^{*}$ & 7.6 \\
\hline SFS & Sulfentrazone & Leaf & $\ldots$ & $\ldots$ & 29.2 & 8.2 \\
\hline SFS & Flumioxazin & Leaf & $\ldots$ & $\ldots$ & 28.4 & 7.6 \\
\hline SFS & Sulfentrazone & Soil & $\ldots$ & $\ldots$ & $25.5^{* *}$ & 7.2 \\
\hline SFS & Flumioxazin & Soil & $\ldots$ & $\ldots$ & $19.0 * * *$ & $6.4^{* *}$ \\
\hline SFS & Azafenidin & Soile & $\ldots$ & $\ldots$ & 0 & 0 \\
\hline
\end{tabular}

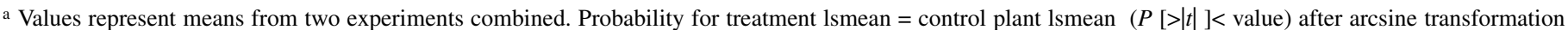
of data: $* * *$, and $* * *=P<0.1,0.05$, and 0.01 , respectively.

b FS = field soil, SFS+P = steamed soil with Pythium arrhenomanes inoculum, and SFS = steamed field soil.

c Root colonization by $P$. arrhenomanes was estimated after Pythium sp. identification.

d Statistical analyses were made after square root transformation of data.

e Not included in statistical analysis. Means indicated are from trial one; treatment was not repeated due to severe plant damage.

TABLE 2. Effects of rate 0.1 herbicide treatments on root colonization by Pythium spp. and root and shoot weight ${ }^{\mathrm{a}}$

\begin{tabular}{|c|c|c|c|c|c|c|}
\hline \multirow[b]{2}{*}{ Soil $^{\mathrm{b}}$} & \multirow[b]{2}{*}{ Herbicide } & \multirow[b]{2}{*}{ Application } & \multicolumn{2}{|c|}{ Length of root colonized (out of $30 \mathrm{~cm}$ ) } & \multirow[b]{2}{*}{ Root weight (g) } & \multirow[b]{2}{*}{ Shoot weight $(\mathrm{g})^{\mathrm{d}}$} \\
\hline & & & Pythium spp. & P. arrhenomanes ${ }^{\mathrm{c}}$ & & \\
\hline FS & Control & None & 7.1 & 4.8 & 10.1 & 4.1 \\
\hline FS & Azafenidin & Leaf & 9.0 & 5.2 & 9.5 & 4.0 \\
\hline FS & Sulfentrazone & Leaf & 5.5 & 3.7 & 10.2 & 4.2 \\
\hline FS & Flumioxazin & Leaf & $3.3 *$ & $2.0 *$ & 10.8 & 4.2 \\
\hline FS & Azafenidin & Soil & 8.9 & 5.6 & $8.2 * *$ & 3.7 \\
\hline FS & Sulfentrazone & Soil & $17.1 * * *$ & 8.9 & 10.1 & 4.1 \\
\hline FS & Flumioxazin & Soil & 8.8 & 4.0 & 9.57 & 4.0 \\
\hline $\mathrm{SFS}+\mathrm{P}$ & Control & None & $\ldots$ & 20.6 & 10.4 & 4.3 \\
\hline $\mathrm{SFS}+\mathrm{P}$ & Azafenidin & Leaf & $\ldots$ & 18.7 & 11.4 & 4.4 \\
\hline $\mathrm{SFS}+\mathrm{P}$ & Sulfentrazone & Leaf & $\ldots$ & $9.2^{* *}$ & 10.7 & 4.7 \\
\hline $\mathrm{SFS}+\mathrm{P}$ & Flumioxazin & Leaf & $\ldots$ & 18.1 & 11.3 & 4.3 \\
\hline $\mathrm{SFS}+\mathrm{P}$ & Azafenidin & Soil & $\ldots$ & 14.7 & 11.3 & 4.3 \\
\hline $\mathrm{SFS}+\mathrm{P}$ & Sulfentrazone & Soil & $\ldots$ & 18.3 & $12.7 *$ & 4.8 \\
\hline $\mathrm{SFS}+\mathrm{P}$ & Flumioxazin & Soil & $\ldots$ & 24.0 & 8.6 & $3.3 *$ \\
\hline SFS & Control & None & $\ldots$ & $\ldots$ & 33.9 & 7.6 \\
\hline SFS & Azafenidin & Leaf & $\ldots$ & $\ldots$ & 28.6 & 8.2 \\
\hline SFS & Sulfentrazone & Leaf & $\ldots$ & $\ldots$ & 31.9 & $9.6 * * *$ \\
\hline SFS & Flumioxazin & Leaf & $\ldots$ & $\ldots$ & 29.4 & $8.9 *$ \\
\hline SFS & Azafenidin & Soil & $\ldots$ & $\ldots$ & $11.6 * * *$ & $4.2 *$ \\
\hline SFS & Sulfentrazone & Soil & $\ldots$ & $\ldots$ & 30.0 & 8.2 \\
\hline SFS & Flumioxazin & Soil & $\ldots$ & $\ldots$ & 33.3 & 7.6 \\
\hline
\end{tabular}

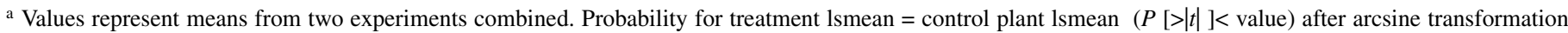
of data: $*, * *$, and $* * *=P<0.1,0.05$, and 0.01 , respectively.

${ }^{\mathrm{b}} \mathrm{FS}=$ field soil, SFS+P = steamed soil with Pythium arrhenomanes inoculum, and SFS = steamed field soil.

${ }^{c}$ Root colonization by $P$. arrhenomanes was estimated after Pythium sp. identification.

d Statistical analyses were made after square root transformation of data. 
concentrations correspond to a 200 -fold dilution of the recommended herbicide rates for field treatment. At this concentration, $P$. arrhenomanes growth was reduced by 67,34 , and $36 \%$ by azafenidin, flumioxazin, and sulfentrazone, respectively. Total growth inhibition of $P$. arrhenomanes was observed at the recommended rate (rate 1) for all three herbicides. Corresponding concentrations of active ingredient alone also were tested. At the lowest concentration used, $0.015,0.0075$, and $0.0075 \mathrm{~g}$ a.i. liter $^{-1}$ for azafenidin, flumioxazin, and sulfentrazone, respectively, $P$. arrhenomanes growth was reduced by 54, 12, and 39\% (Fig. 5A).

For $P$. aphanidermatum, the growth reduction observed at the 200 -fold dilution of the recommended herbicide rate (rate 1)

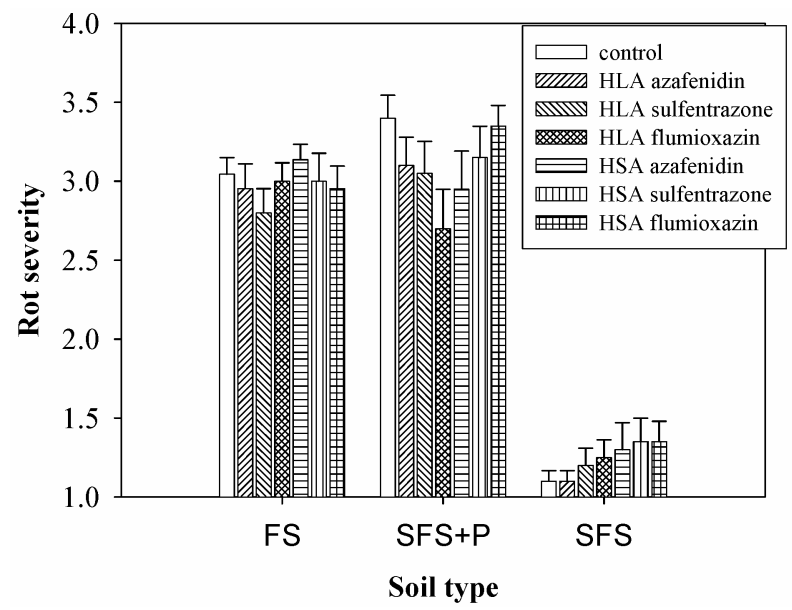

Fig. 2. Effect of herbicides applied at rate 0.1 on root rot severity rating estimated on a 1-to-4 scale. Bars represent means of results from two experiments combined, and error bars are the standard error of the mean. $\mathrm{FS}=$ field soil, SFS $=$ steamed field soil, and SFS $+\mathrm{P}=$ steamed soil with Pythium arrhenomanes inoculum. HSA $=$ herbicides applied to soil, and HLA = herbicide applied to leaves.

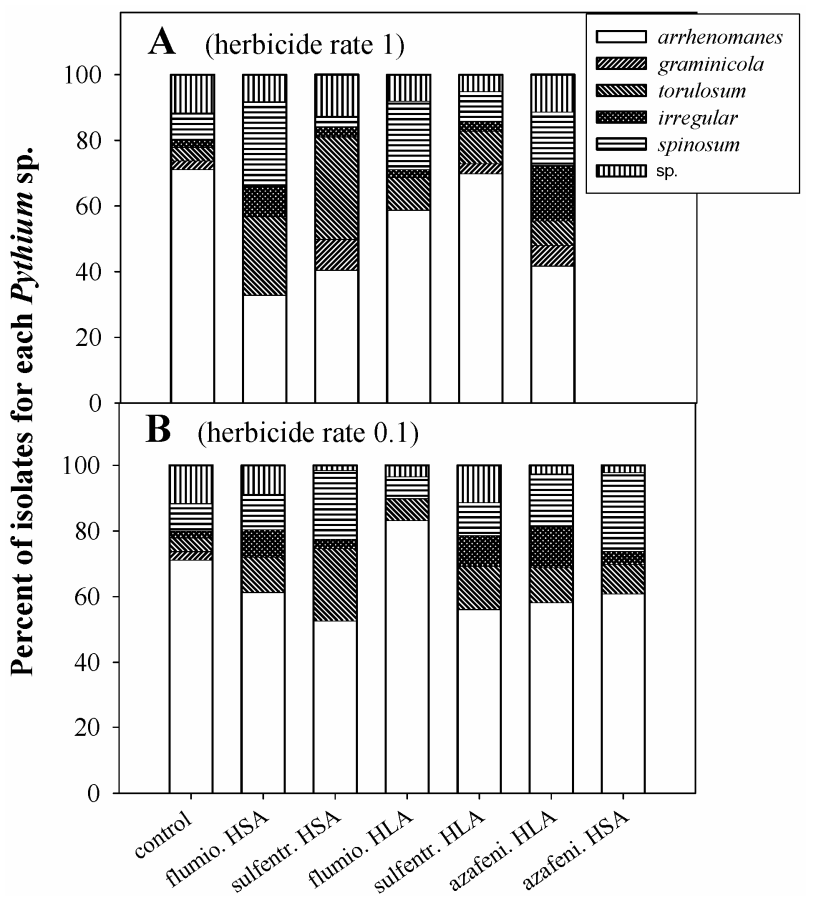

Fig. 3. Frequency of isolation for five Pythium spp. and unidentified Pythium spp. from roots of sugarcane grown in field soil after herbicides were applied at $\mathbf{A}$, the recommended rate and $\mathbf{B}, 1 / 10$ of the recommended rate. Control $=$ nontreated plants, flumio $=$ flumioxazin, sulfentr $=$ sulfentrazone, azafeni $=$ azafenidin, HSA = herbicides applied to soil, and HLA = herbicide applied to leaves. ranged from 12 to $54 \%$ depending on the herbicide. Complete inhibition of $P$. aphanidermatum was observed only for azafenidin at a $2 \times$ concentration of the recommended rate. Maximum growth inhibition for the two other herbicides ranged from 85 to $90 \%$ at the $2 x$ concentration of the recommended rate (Fig. 5B). For $P$. ultimum, growth reductions observed at the full rate 200 -fold dilution of the herbicides ranged from 5 to $43 \%$ depending on herbicide. Complete inhibition of $P$. ultimum was observed for azafenidin for the recommended rate concentration. Maximum growth inhibition for the two other herbicides occurred at a $2 \times$ concentration of the recommended rate. The reductions were 62 and $99 \%$ for flumioxazin and sulfentrazone, respectively (Fig. 5C). Mycelial growth inhibition caused by the corresponding active ingredient concentrations generally was less for azafenidin and flumioxazin but not sulfentrazone (Fig. 5).

\section{DISCUSSION}

The first research investigating the effects of PPOase inhibitor herbicides on Sclerotinia stem rot of soybean was stimulated by
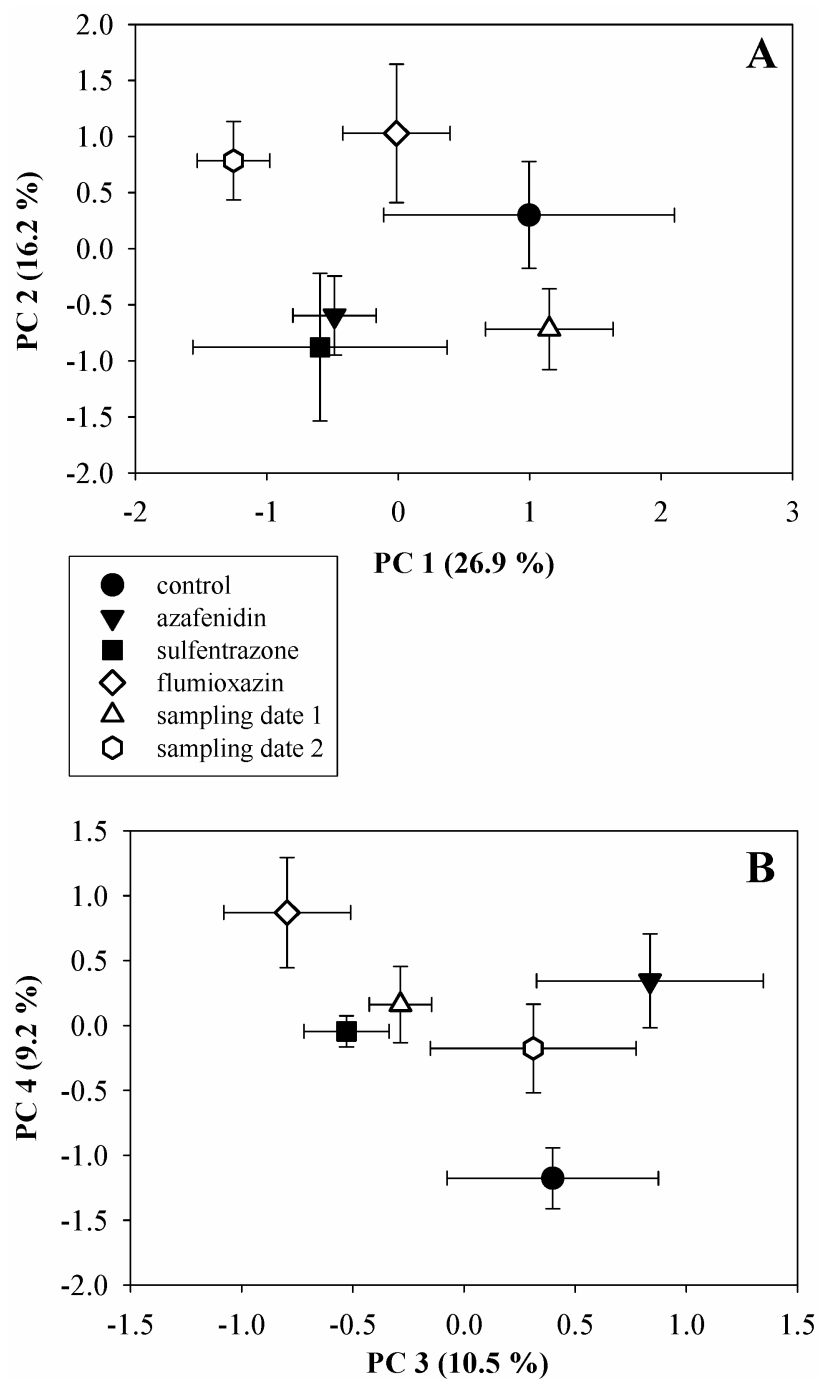

Fig. 4. Effects of three herbicides on soil microbial community functional diversity analyzed by principal component (PC) analysis performed on sole carbon source utilization profiles from treatments with herbicides applied to soil at the recommended rate. A, First and second PC axis; B, third and fourth $\mathrm{PC}$ axis. The two dates of sampling were combined for the herbicide treatment ordination plot of PC and herbicide treatments were combined for each date of sampling ordination plot of PC. Error bars represent standard error of the mean. Values in parentheses indicate the percent of total variation accounted for by each principal component axis. 
field observations of reduced symptom severity and enhanced growth for treated plants (3). Sclerotinia spp. reside in the soil, but the disease affects aboveground portions of the plant. Similar field observations of increased growth occasionally were made for sugarcane plants treated with azafenidin, but changes in foliar disease symptoms were not observed. This suggested the possibility that plant growth increases might be due to the suppression of root disease. Pythium root rot adversely affects plant growth of sugarcane in Louisiana $(12,25)$; therefore, research was conducted to evaluate possible effects of PPOase inhibitor herbicides on Pythium spp. and root rot.

Research evaluating the effects of this class of herbicides on soilborne pathogens and root diseases has been conducted. PPOase inhibitor herbicides applied to soybean plants, but not to soil, resulted in the production and accumulation of a phytoalexin, glyceollin, in roots, and reduced reproduction of the soybean cyst nematode was observed (18). However, herbicide application did not increase yield (2). Lactofen, a PPOase inhibitor herbicide in the diphenyl ether chemical family, did not reduce severity of Rhizoctonia root rot and damping-off in soybean (11). In contrast, acifluorfen, another diphenyl ether herbicide, reduced Rhizoctonia foliar blight intensity in soybean (1).

In this study, there were no consistent beneficial effects on sugarcane from applications of three PPOase inhibitor herbicides, azafenidin, flumioxazin, and sulfentrazone. Herbicide treatments resulted in plant injury. This is crucial for the induction of resistance, but some treatments resulted in significant reductions in growth of plants in SFS. It may be that the duration of the experiments was not long enough for plants to recover from herbicide phytotoxicity effects. The artificial growing conditions inherent in greenhouse experiments also may have prevented the detection of treatment effects. The 0.1 rate was included to investigate the effects of less injurious treatments; however, no significant increases in plant growth resulted from these treatments.

There also were no consistent effects from herbicide treatments on disease parameters. However, some of the results provided evidence suggesting herbicide treatment effects on root rot severity. Flumioxazin applied to leaves at the 0.1 rate in SFS with $P$. arrhenomanes reduced the root rot severity rating, and sulfentrazone applied to leaves at the 0.1 rate in SFS+P reduced root colonization by $P$. arrhenomanes. In addition, multiple treatments changed the relative frequency of isolation of different Pythium spp. from the roots and reduced the portion of the root system

TABLE 3. Most important carbon substrates for explaining variability in substrate utilization among soils treated with different herbicides based on substrate eigenvector value for principal component one (PC1) to $\mathrm{PC} 4^{\mathrm{a}}$

\begin{tabular}{lllll}
\hline Substrates & PC1 & PC2 & PC3 & PC4 \\
\hline Carbohydrates & & & & \\
$N$-Acetyl-D-galactosamine & 0.20 & 0.46 & 0.11 & 0.05 \\
$N$-Acetyl-D-glucosamine & 0.18 & 0.02 & 0.36 & 0.02 \\
D-Arabitol & 0.14 & 0.11 & 0.22 & 0.16 \\
Cellobiose & 0.02 & 0.23 & 0.01 & 0.19 \\
Gentiobiose & 0.02 & 0.28 & 0.06 & 0.28 \\
D-Mannose & 0.39 & 0.06 & 0.01 & 0.08 \\
D-Melibiose & 0.24 & 0.26 & 0.42 & 0.03 \\
B-Methyl-D-glucoside & 0.03 & 0.04 & 0.09 & 0.42 \\
D-Psicose & 0.14 & 0.34 & 0.14 & 0.02 \\
D-Raffinose & 0.16 & 0.24 & 0.39 & 0.29 \\
L-Rhamnose & 0.24 & 0.12 & 0.06 & 0.13 \\
Maltotriose & 0.18 & 0.09 & 0.00 & 0.21 \\
D-Sorbitol & 0.38 & 0.02 & 0.18 & 0.04 \\
Carboxylic acids & & & & \\
$\quad$ D-Galacturonic acid & 0.09 & 0.08 & 0.21 & 0.00 \\
Amide & & & & \\
Succinamic acid & 0.22 & 0.16 & 0.17 & 0.47 \\
Aromatics & & & & \\
Urocanic acid & 0.22 & 0.02 & 0.17 & 0.02 \\
\hline
\end{tabular}

a Only eigenvectors with $|x|>0.20$ for at least one PC are presented. colonized by $P$. arrhenomanes. Previous research (17) suggested that the percentage of Pythium spp. colonizing the roots composed by $P$. arrhenomanes is an important determinant of root rot severity in sugarcane.

Herbicides may modify the competitiveness of soil microorganisms, and Pythium spp. apparently are very sensitive to PPOase inhibitor herbicides. At a low concentration, all three herbicides tested inhibited mycelial growth of three different plant-pathogenic Pythium spp., and $P$. arrhenomanes exhibited the greatest inhibition. P. ultimum was less sensitive to flumioxazin than to the other two herbicides. Formulated products of azafenidin and flumioxazin were more inhibitory to mycelial growth of Pythium spp. than the active ingredient for each, whereas sulfentrazone formulated product and active ingredient were equally effective. Treatments in which herbicides were applied to the soil surface were most effective in reducing root colonization by Pythium spp. However, plants growing in the field produce an extensive root system, and exposure of Pythium spp. to direct herbicide toxicity throughout the soil profile where roots develop would be difficult to achieve.

Sole carbon source utilization profiles have been used to characterize microbial communities in soils planted with agricultural

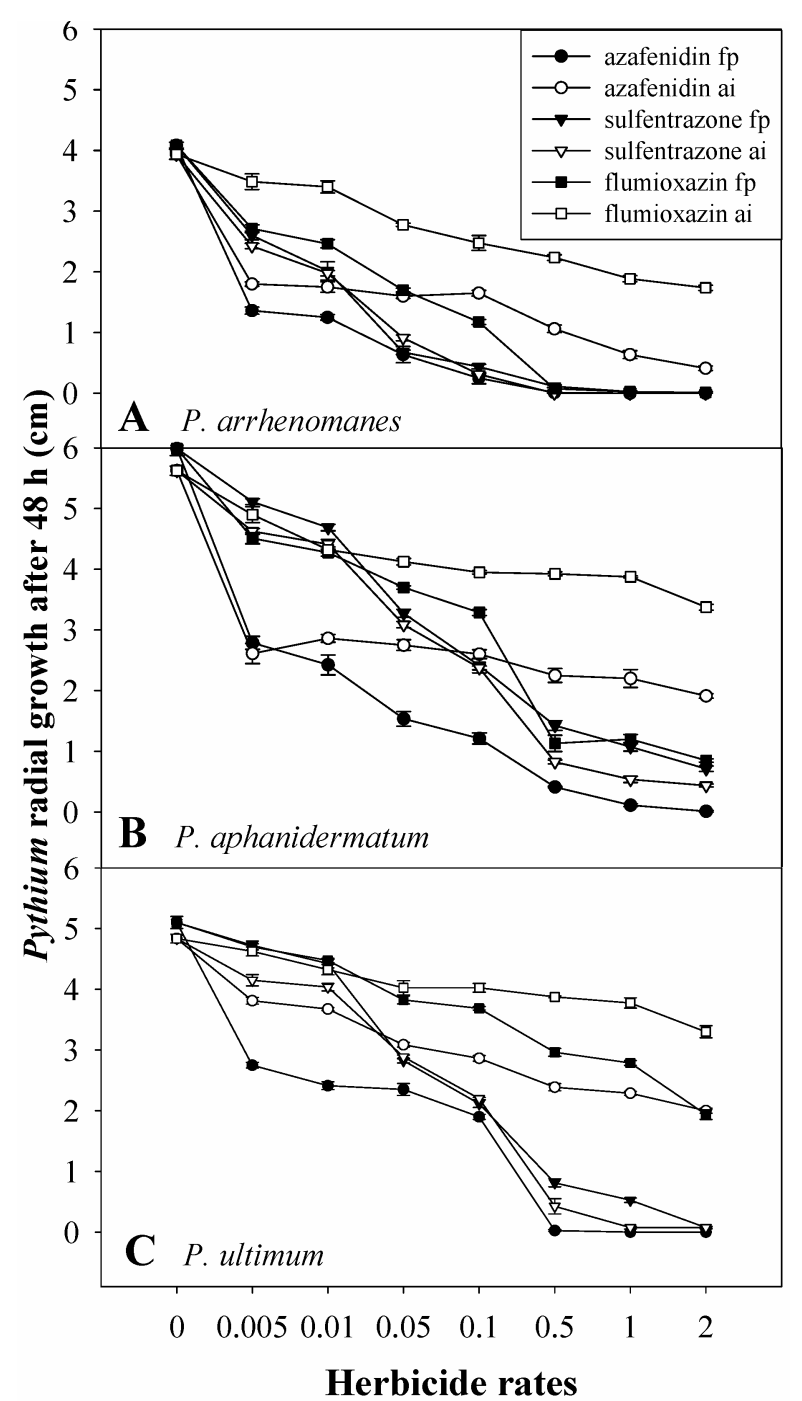

Fig. 5. Herbicide effects on in vitro mycelial growth of three Pythium spp.: A, Pythium arrhenomanes, $\mathbf{B}, P$. aphanidermatum, and $\mathbf{C}$, P. ultimum. Rate 1 was the recommended rate and corresponded to an amendment of $3,1.5$, and $1.5 \mathrm{~g}$ liter ${ }^{-1}$ of herbicide active ingredient in culture medium for azafenidin, flumioxazin, and sulfentrazone, respectively. Error bars represent the standard error of the mean from two experiments; $\mathrm{fp}=$ commercial formulated product of the herbicide and ai = herbicide active ingredient only. 
crops and exposed to different treatments $(5,16,19)$. This technique detected alterations in the soil microbial community resulting from treatment with three PPOase inhibitor herbicides, as was observed for phenylurea herbicides (5). The communities in soils treated with the different herbicides also were distinguishable. Major substrates affected were carbohydrates. Carbohydrates were shown to be involved in microbial community differentiation under different potato cropping systems (16), cropping systems that may affect soilborne diseases (15). Research has focused recently on the role of the total microbial community on root health and sugarcane growth and yield $(20,24)$. In addition to possible direct effects of herbicides on Pythium spp., alterations in the soil microbial community resulting from exposure to PPOase inhibitor herbicides might affect root disease severity in the field.

Suppression of disease associated with PPOase inhibitor herbicide treatments has been linked to induced resistance mechanisms, such as phytoalexin accumulation or the hypersensitive response (14). Gyceollin accumulation is associated with the expression of resistance to Phytophthora spp., organisms closely related to Pythium spp., but the effect of herbicides on this association has been studied only with glyphosate (13) and not with PPOase inhibitor herbicides. Pythium spp. are nonspecialized pathogens capable of infecting immature root and seedling tissues in multiple hosts. The experimental results with Rhizoctonia spp. (11) and Pythium spp. suggest that disease resistance that may be induced by herbicides is not effective in root diseases with a low level of specificity between host and pathogen.

\section{LITERATURE CITED}

1. Black, B. D., Russin, J. S., Griffin, J. L., and Snow, J. P. 1996. Herbicide effects on Rhizoctonia solani in vitro and Rhizoctonia foliar blight of soybean (Glycine max). Weed Sci. 44:711-716.

2. Browde, J. A., Pedigo, L. P., Owen, M. D. K., and Tylka, G. L. 1993. Soybean yield and pest management as influenced by nematodes, herbicides, and defoliating insects. Agron. J. 68:601-608.

3. Dann, E. K., Diers, B. W., and Hammerschmidt, R. 1999. Suppression of Sclerotinia stem rot of soybean by Lactofen herbicide treatment. Phytopathology 89:598-602.

4. Dissanayake, N., Hoy, J. W., and Griffin, J. L. 1998. Herbicide effects on sugarcane growth, Pythium root rot, and Pythium arrhenomanes. Phytopathology 88:530-535.

5. EL Fantroussi, S., Vershuere, L., Verstraete, W. L., and Top, E. M. 1999. Effect of phenylurea herbicides on soil microbial communities estimated by analysis of $16 \mathrm{~S}$ rRNA gene fingerprints and community-level physiological profiles. Appl. Environ. Microbiol. 65:982-988.

6. Gagliardi, J. V., Buyer, J. S., Angle, J. S., and Russek-Cohen, E. 2001. Structural and functional analysis of whole-soil microbial communities for risk and efficacy testing following microbial inoculation of wheat roots in diverse soils. Soil Biol. Biochem. 33:25-40.

7. Garland, J. L., and Mills, A. L. 1991. Classification and characterization of heterotrophic microbial communities on the basis of patterns of community-level sole-carbon source utilization. Appl. Environ. Microbiol. 57:2351-2359.

8. Garside, A. L., Bramley, R. G. V., Bristow, K. L., Holt, J. A., Magarey, R. C., Nable, R. O., Pankhurst, C. E., and Skjemstad, J. O. 1997. Comparisons between paired old and new land sites for sugarcane growth and yield and soil chemical, physical, and biological properties. Proc. Aust. Soc. Sugar Cane Technol. 19:60-66.
9. Glimm, E., Heuer, H., Engelen, B., Smalla, K., and Backhaus, H., 1997. Statistical comparisons of community catabolic profiles. J. Microbiol. Methods 30:71-80.

10. Greaves, M. P., and Malkomes, M. P. 1980. Effects on soil microflora. Pages 223-253 in: Interactions Between Herbicides and the Soil. R. J. Hance, ed. Academic Press, New York.

11. Harikrishnan, R., and Yang, X. B. 2002. Effects of herbicides on root rot and damping-off caused by Rhizoctonia solani in glyphosate-tolerant soybean. Plant Dis. 86:1369-1373.

12. Hoy, J. W., and Schneider, R. W. 1988. Role of Pythium in sugarcane stubble decline: Pathogenicity and virulence of Pythium species. Phytopathology 78:1688-1692.

13. Keen, N. T., Holliday, M. J., and Yoshikawa, M. 1982. Effects of glyphosate on glyceollin production and the expression of resistance to Phytophthora megasperma f. sp. glycinea in soybean. Phytopathology 72:1467-1470

14. Landini, S., Graham, M. Y., and Graham, T. L. 2003. Lactofen induces isoflavin accumulation and gyceollin elicitation competency in soybean. Phytochemistry 62:865-874.

15. Larkin, R. P. 2002. Effects of different 3-yr cropping systems on Rhizoctonia canker and black scurf of potato in northern Maine, 2000 and 2001. Biol. Cult. Tests Control Plant Dis. 17:PT07.

16. Larkin, R. P. 2003. Characterization of soil microbial communities under different potato cropping systems by microbial population dynamics, substrate utilization, and fatty acid profiles. Soil Biol. Biochem. 35:14511466.

17. Lee, Y. S., and Hoy, J. W. 1992. Interactions among Pythium species affecting root rot of sugarcane. Plant Dis. 76:735-739.

18. Levene, B. C., Owen, M. D. K., and Tylka, G. L. 1998. Response of soybean cyst nematodes and soybeans (Glycine max) to herbicides. Weed Sci. 46:264-270

19. Lupwayi, N. Z., Rice, W. A., and Clayton, G. W. 1998. Soil microbial diversity and community structure under wheat as influenced by tillage and crop rotation. Soil Biol. Biochem. 30:1733-1741.

20. Magarey, R. C. 1996. Microbial aspects of sugarcane yield decline. Aust. J. Agric. Res. 47:307-322.

21. Magarey, R. C. 1999. Reduced productivity in long-term monoculture: Where are we placed? Aust. Plant Pathol. 28:11-20.

22. Nelson, K. A., Renner, K. A., and Hammerschmidt, R. 2002. Cultivar and herbicide selection affects soybean development and the incidence of Sclerotinia stem rot. Agron. J. 94:1270-1281.

23. Nelson, K. A., Renner, K. A., and Hammerschmidt, R. 2002. Effects of protoporhyrinogen oxidase inhibitors on soybean (Glycine max L.) response, Sclerotinia sclerotiorum disease development, and phytoalexin production by soybean. Weed Technol. 16:353-359.

24. Pankhurst, C. E., Hawke, B. G., Holt, J. A., Magarey, R. C., and Garside, A. L. 2000. Effect of rotation breaks on the diversity of bacteria in the rhizosphere of sugarcane and its potential impact on yield decline. Proc. Aust. Soc. Sugar Cane Technol. 22:77-83.

25. Rands, R. D., and Dopp, E. 1938. Pythium root rot of sugarcane. U.S. Dep. Agric. Tech. Bull. 666.

26. Simon-Sylvestre, G., and Fournier, J. C. 1979. Effects of pesticides on the soil microflora. Adv. Agron. 31:1-92.

27. Smalla, K. 1998. Analysis of Biolog GN substrate utilization patterns by microbial communities. Appl. Environ. Microbiol. 64:1220-1225.

28. Staddon, W. J., Duchesne, L. C., and Trevors, J. T. 1997. Microbial diversity and community structure of postdisturbance forest soils as determined by sole-carbon-source utilization patterns. Microbial Ecol. 34:125130.

29. Van der Plaats-Niterink, A. J. 1981. Monograph of the genus Pythium. Stud. Mycol. 21:1-242.

30. Viator, B. J., Griffin, J. L., and Ellis, J. M. 2002. Red morningglory (Ipomoea coccinea) control with sulfentrazone and azafeniden applied at layby in sugarcane (Saccharum spp.). Weed Technol. 16:142-148. 